\title{
Phyto-Zooplankton Community in Coastal Waters of Western Sweden - An Ecosystem Off Balance?
}

\author{
Odd Lindahl and Lars Hernroth
}

Kristineberg Marine Biological Station, S-450 34 Fiskebäckskil, Sweden

\begin{abstract}
A baseline study of the phyto- und zooplankton community was carried out from 1978 to 1981 in, what was supposed to be, a relatively undisturbed fjord on the west coast of Sweden. Heavy phytoplankton blooms were found during spring and autumn. Chlorophyll $a$ and cell numbers were far above normal. Extremely low zooplankton biomass during the spring bloom and high abundance of scyphomedusae (which preyed on zooplankton during the summer) resulted in low grazing pressure and probably led to increased sedimentation of organic matter. Oxygen deficit has occurred in bottom waters of the fjord in the absence of adequate exchange. It was not possible to determine whether this series of events is due to natural fluctuations or man-made influences.
\end{abstract}

\section{INTRODUCTION}

A baseline study on hydrography and the plankton community has been carried out in the Gullmar Fjord beginning in 1978. The fjord is situated on the west coast of Sweden (Fig. 1) and it is Sweden's only typical fjord in the sense that it has a distinct sill. The fjord is $30 \mathrm{~km}$ long and $3 \mathrm{~km}$ wide; it has a maximum depth of $120 \mathrm{~m}$ and a sill depth of $45 \mathrm{~m}$. On several occasions during this study, the authors encountered what were thought to be exceptional conditions. While some of these observations are presented, our main objective is to describe the hitherto unknown ecological situation and the possible factors or combination of factors which initiate plankton blooms in the fjord.

\section{STUDY AREA}

Waters along the west coast of Sweden are, with some few local exceptions, considered relatively clean. This is especially true for the Gullmar Fjord, where there are no major sources of water pollution from either sewage or industrial origin. In fact, the fjord will probably become Sweden's first marine reservation. The water body in the fjord is always stratified (Fig. 2). Normally the water column consists of 3 layers, each of different origin: high salinity $(>34 \%$ S) water from the North Sea in the deep basin of the fjord (below $50 \mathrm{~m}$

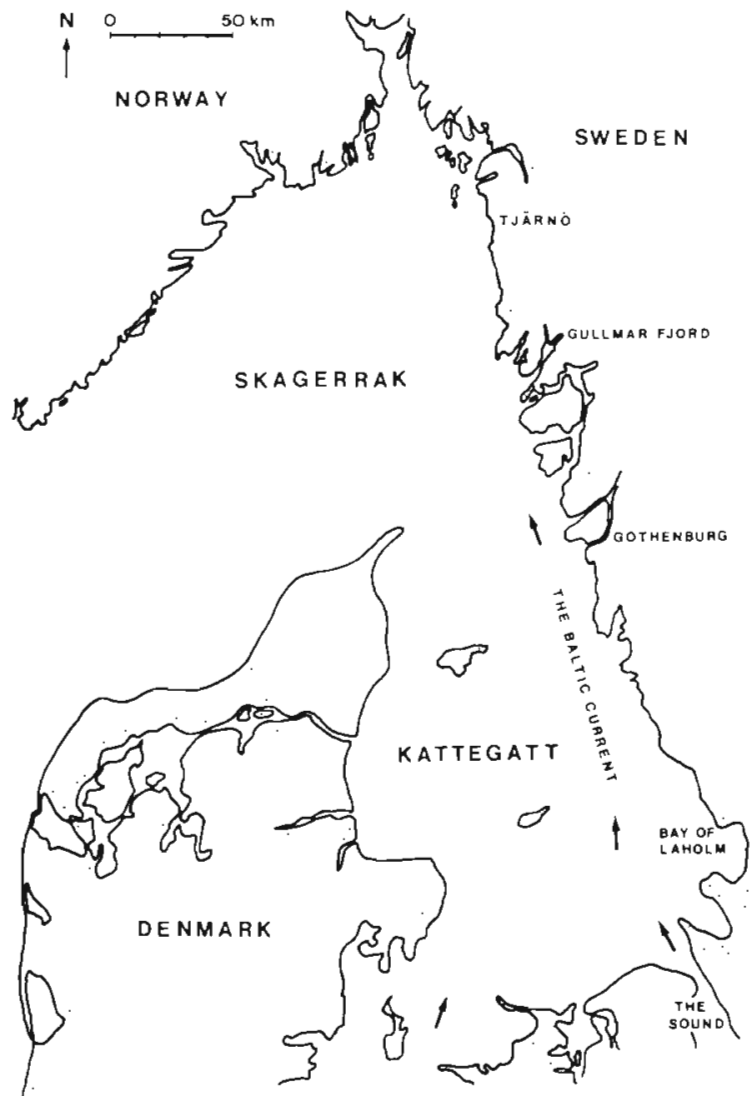

Fig. 1. Map of Kattegatt, Skagerrak and west coast of Sweden 
depth); water from the Skagerrak area (31 to $33 \%$ S) forming an intermediate layer (normally 20 to $50 \mathrm{~m}$ ); water originating from the Baltic Sea $(<30 \%$ S) comprising the top layer. Baltic water is transported to the fjord-area by the Baltic current (Fig. 1) running north-

$$
\text { SALINITY STRATIFICATION IN THE GULLMAR FJORD }
$$

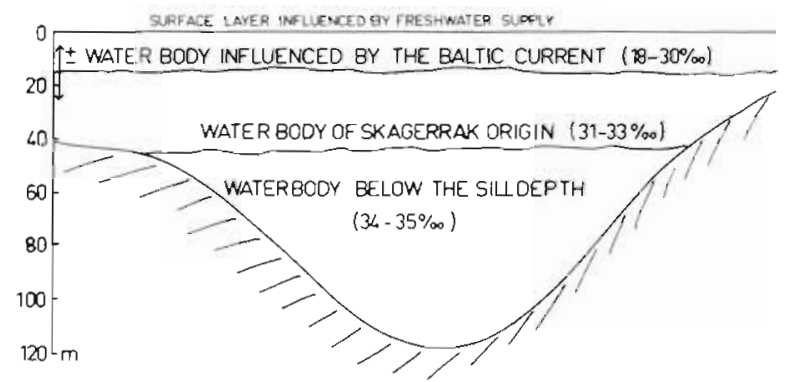

Fig. 2. Vertical stratification of water masses in the Gullmar Fjord

wards along the coast. On some occasions there can also be a thin layer of almost fresh water in the fjord resulting from local runoff. A thermocline is more or less pronounced from May until September, normally at 15 to $20 \mathrm{~m}$ depth.

Occurrence and vertical distribution of the different water masses are determined by wind and barometric pressure changes. Baltic-current water, which dominates the euphotic zone of the fjord, is probably enriched with nutrients from populated areas upcurrent. Exchange of water below sill depth normally occurs during late winter or early spring when densities are highest and wind conditions permit deep circulation (Fig. 3).

\section{MATERIAL AND METHODS}

Field and laboratory work was carried out employing standard methods used in baseline studies. Sampling was performed about 30 times each year and distributed in such a way that the dynamics of the pelagic community could be followed, that is, weekly during spring and autumn, every second week in summer and once a month in winter.

\section{Hydrography}

Hydrographic samples were taken with water bottles at standard depths $(0,5,10,15,20,25,30,40, \ldots 110$ and $120 \mathrm{~m}$ ). Temperature was measured using reversing thermometers; salinity, a laboratory salinometer (Grundy mod. 6230N); oxygen, a modified Winkler technique according to Carrit and Carpenter (1966). Phosphate analyses were carried out according to Strickland and Parsons (1968).

\section{Phytoplankton}

Chlorophyll a measurements were carried out either on integrated samples taken with a $12 \mathrm{~m}$ long hose or on discrete samples taken from $0,5,10$ and $15 \mathrm{~m}$ depths. The volume in either case was 21 , following recommendations of the Baltic Marine Biologists (BMB, 1979). For computing the results, equations of Strickland and Parsons (1960) were applied. Cell counts were carried out on integrated samples preserved with neutralized formaldehyde. Cell counting

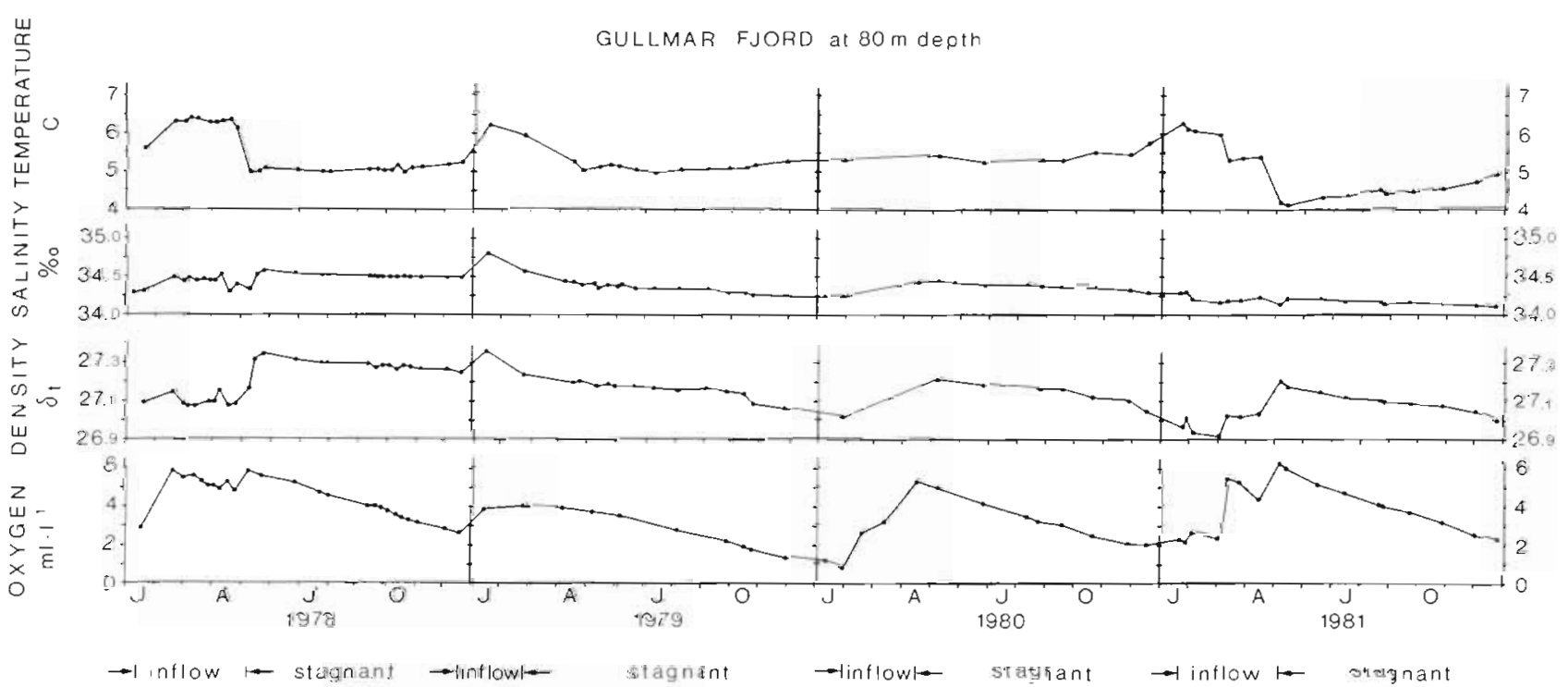

Fig. 3. Temperature $\left({ }^{\circ} \mathrm{C}\right)$, salinity $(\% \mathrm{~S})$, density $\left(\delta_{t}\right)$ and oxygen content $\left(\mathrm{mI}^{-1}\right)$ at $80 \mathrm{~m}$ depth in the Gullmar Fjord 1978 to 1981 
and biomass calculations were performed according to the manual of the Baltic Marine Biologists (BMB, 1979).

For primary production measurements we employed the ${ }^{14} \mathrm{C}$-technique in situ at 8 depths $(0,2,4,6,8,10,15$ and $20 \mathrm{~m}$ ) with $4 \mathrm{~h}$ incubation time. The radioactivity was measured by liquid scintillation counting technique. Recommendations of BMB (1976) were followed throughout primary production measurements.

\section{Zooplankton}

Mesozooplankton samples were taken with vertical hauls, from bottom to surface, using a standard UNESCO WP II $90 \mu \mathrm{m}$ net. Counting and biomass determinations were standardized (BMB, 1976). Microzooplankton samples were taken with water bottles at 4 depths $(0,5,10,15 \mathrm{~m})$ and analysed according to Utermöhl (1958).

\section{RESULTS}

\section{Hydrography}

In the present context, 2 hydrographical processes are of special interest: (1) in-and outflow of water above sill depth; (2) periodic exchange of deep water. Rydberg (1977) demonstrated that the water volume $\left(1.55 \mathrm{~km}^{3}\right)$ above sill depth is exchanged within less than 1 mo. This flow is driven by vertical movements of the halocline outside the fjord. Several biological observations have shown that events outside the fjord occur more or less simultaneously inside (A. Josefson, T. Lundälv, pers. comm.). These results and experience demonstrate that investigations in the euphotic part of the pelagic ecosystem inside the fjord are representative of a larger area adjacent to the Swedish west coast. Fig. 3 shows temperature, salinity, density and oxygen conditions at $80 \mathrm{~m}$ in the fjord. Inflows of deep water are witnessed by changes in density and oxygen. They were followed by periods during which water stagnated and the oxygen was gradually consumed. It appears that there have been yearly exchanges during winter and early spring. However, the weak exchange in 1979 led to extremely low oxygen content of the deep water by the end of that year. There are 2 possible explanations for this: (1) a small quantity of water was exchanged, or (2) the replacing water had a low oxygen content to start with. This resulted in oxygen values near the bottom during the winter 1979/80 of only $0.21 \mathrm{ml} \mathrm{O}_{2} 1^{-1}$ (January 1980), the lowest value ever recorded in the fjord.

Phosphate is the only nutrient which has been regularly measured. Long-term data from the fjord show no increase in surface- or deep-water values during the last 2 decades. Winter values in the surface water ranged from 0.5 to $0.7 \mu \mathrm{g}$ at $\mathrm{l}^{-1}$, with a mean of 0.57 (unpubl. data, Hydrographical Lab., Fish. Bd of Sweden). Following the spring bloom, most phosphate values were low throughout the photosynthetic season

\section{Phytoplankton}

Primary production curves (Fig. 4) are complex. Daily production during the first half of the productive season was ca. $500 \mathrm{mg} \mathrm{C} \mathrm{m} \mathrm{C}^{-2} \mathrm{~d}^{-1}$; during the second half, ca. 800 (there were several large deviations from these figures). Peak values ranged from 1,400 to

\section{GULLMAR FJORD}

$$
\text { PRIMARY PRODUCTION }
$$

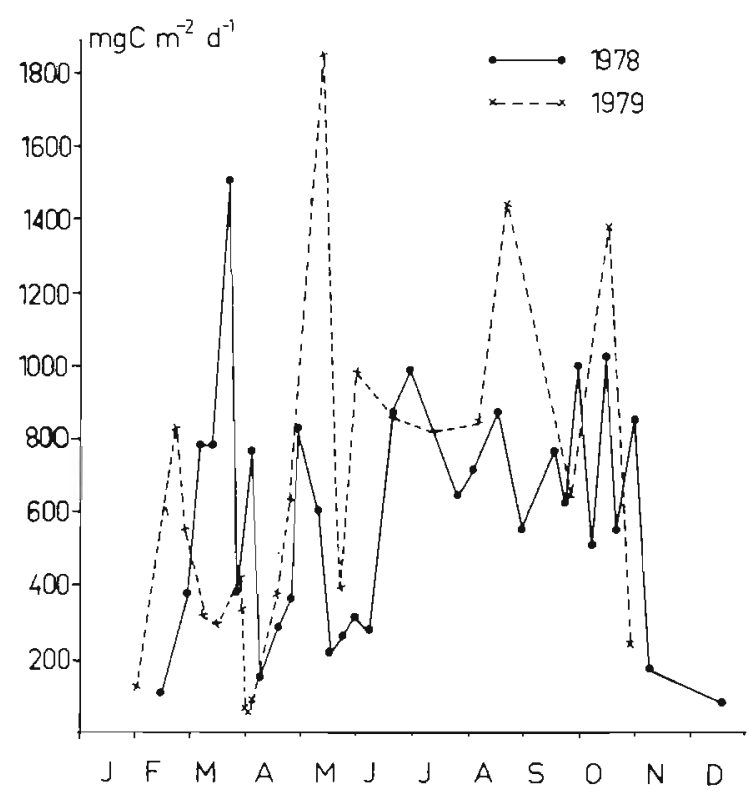

Fig. 4. Calculated daily primary production $\left(\mathrm{mg} \mathrm{C} \mathrm{m}^{-2} \mathrm{~d}^{-1}\right)$ in the Gullmar Fjord 1978 to 1979

$1,800 \mathrm{mg} \mathrm{C} \mathrm{m} \mathrm{m}^{-2} \mathrm{~d}^{-1}$, with several values below 300 , especially during spring. The calculated yearly production for 1978 and 1979 was 180 and $230 \mathrm{~g} \mathrm{C} \mathrm{m}^{-2}$, respectively, including exudate.

Chlorophyll a values in the euphotic zone (Fig. 5) document a general trend with high values during spring and autumn, and low values in between. Peak values ranged from 15 to $25 \mathrm{mg} \mathrm{Chl} \mathrm{m} \mathrm{m}^{-3}$ or 180 to 300 $\mathrm{mg} \mathrm{Chl} \mathrm{m}^{-2}$ integrated for the euphotic layer. In autumn 1981 corresponding values of $66 \mathrm{mg} \mathrm{Chl} \mathrm{m}^{-3}$ and $800 \mathrm{mg} \mathrm{Chl} \mathrm{m}{ }^{-2}$ were found. It is apparent that the bloom during autumn 1981 was of extreme magnitude 


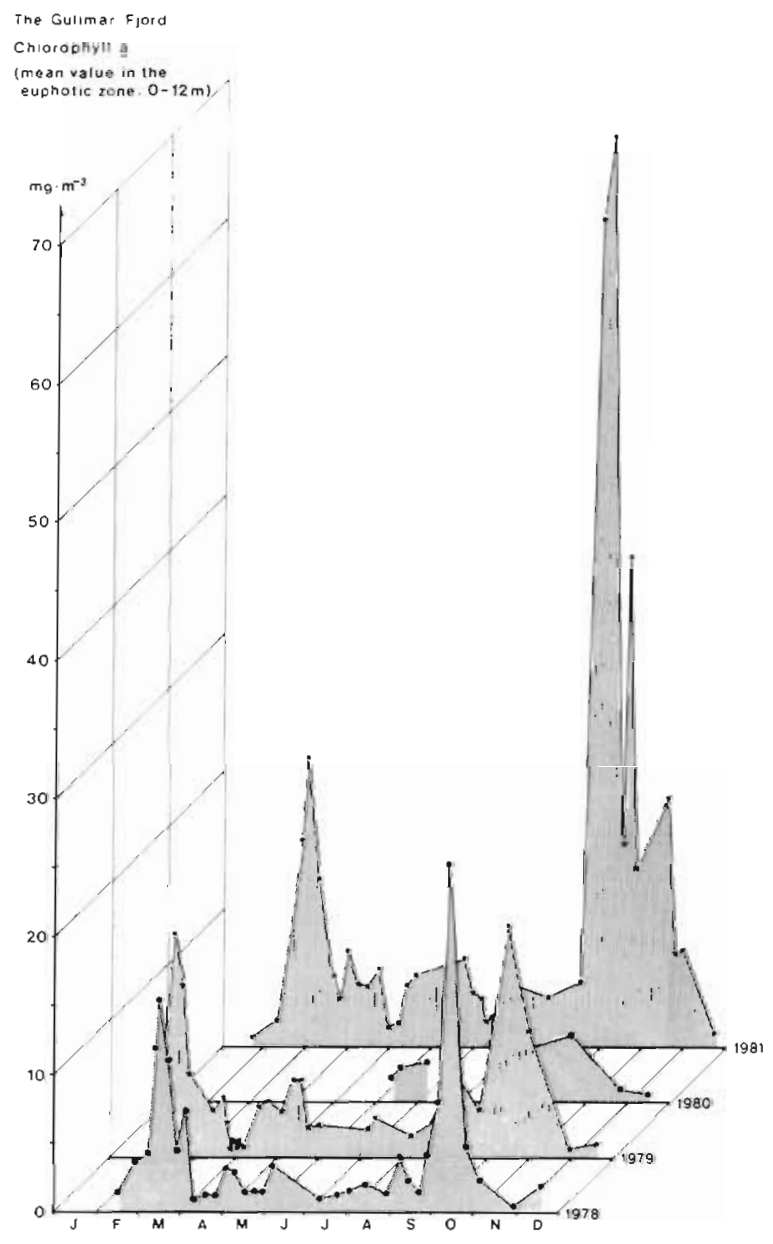

Fig. 5. Amount of chlorophyll a $\left(\mathrm{mg} \mathrm{m}^{-3}\right)$ in the Gullmar Fjord 1978 to 1981 ; mean values in the euphotic zone ( 0 to $12 \mathrm{~m}$ )

when compared with earlier blooms, Chlorophyll a

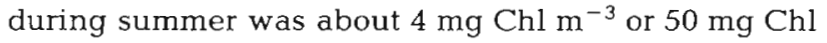
$\mathrm{m}^{-2}$ integrated for the euphotic layer.

Biomass was measured regularly (excluding nanoplankton) by means of cell counts. The spring bloom was completely dominated by diatoms, especially Skeletonema costatum. Dinoflagellates dominated during late spring and summer, together with a variety of diatoms. At the end of summer and during autumn, Ceratium spp. became abundant; on some occasions during the autumns of 1978 and 1979 it completely dominated the biomass. The tremendous peak of 1981 was, however, caused by another species - the dinoflagellate Gyrodinium aureolum. During winter the flora was poor, consisting mainly of various diatoms and ceratia.

There are some peak values in cell numbers worth special notice. In October 1978, approximately $5.7 \times$ $10^{5}$ cells $1^{-1}$ were found resulting in a biomass of $2.1 \mathrm{~g}$ $\mathrm{C} \mathrm{m}^{-3}$ as a mean value for the euphotic zone, or $25 \mathrm{~g} \mathrm{C}$ $\mathrm{m}^{-2}$ integrated for the euphotic layer. The dominating species were Ceratium furca, C. fusus and Prorocentrum micans. In October $1979,2.5 \times 10^{5}$ cells $l^{-1}$ were found with a biomass of $1.3 \mathrm{~g} \mathrm{C} \mathrm{m}^{-3}\left(16{\mathrm{~g} \mathrm{C} \mathrm{m}^{-2}}^{-2}\right.$ integrated). The dominating species on this occasion were C. furca and C. lineatum. In March 1981, Skeletonema costatum reached $53 \times 10^{6}$ cells $1^{-1}$, with a biomass of $1.5 \mathrm{~g} \mathrm{C} \mathrm{m}^{-3}$ ( $18 \mathrm{~g} \mathrm{C} \mathrm{m}^{-2}$ integrated), In the huge bloom of Gyrodinium aureolum of October 1981, a maximum of $11.4 \times 10^{6}$ cells $1^{-1}$ was found with a biomass of $36 \mathrm{~g} \mathrm{C} \mathrm{m}^{-3}$ (430 $\mathrm{g} \mathrm{C} \mathrm{m}^{-2}$ integrated). Further to the north along the Swedish coast where dead fish were found, our samples contained $35.3 \times$ $10^{6}$ cells $l^{-1}$; this corresponds to the densities recorded in a typical 'red tide' (ICES, 1976).

\section{Zooplankton}

Qualitatively, the plankton-fauna composition can be characterized as follows: The first months of the year are extremely poor in zooplankton (Fig. 6); only a small population of copepods in diapause inhabit the deeper layers, and the water column above sill depth is practically uninhabited. In March a short but intense period of increase of barnacle nauplii occurs. In April and May there is a slow but consistent build-up of the abundance in the copepod community, both in surface and deeper layers. Simultaneously, there are 2 rapid and important blooms: one of protozooplankton (ciliates, up to $45 \times 10^{7}$ ind. $\mathrm{m}^{-2}$ in the euphotic zone) and one of rotifers (Synchaeta spp. up to $1.5 \times 10^{6}$ ind.

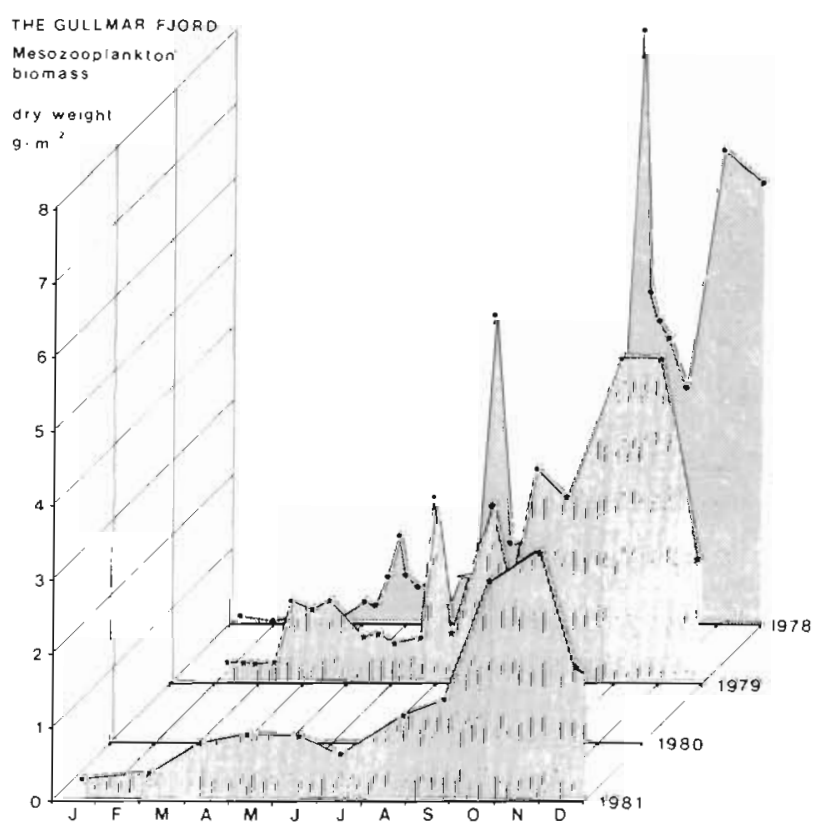

Fig. 6. Mesozooplankton biomass expressed as dry weight ( $g$ $\mathrm{m}^{-2}, 120$ to $0 \mathrm{~m}$ ) in the Gullmar Fjord 1978 to 1979 and 1981 . Time axis reversed, compared to Fig. 5, due to the reversed development of phyto- and zooplankton biomass 
$\mathrm{m}^{-2}$ ). Although the biomass is still small $(\sim 1 \mathrm{~g} d r y$ weight $\mathrm{m}^{-2}$ ), these blooms are of great importance to the transfer of energy due to high reproduction rates of these organisms.

As expected, summer months with increasing water temperatures promote a diversity of zooplankton species. Beside the copepods, the cladocerans (Evadne nordmanni, Podon spp. and Pleopsis polyphemoides) are at times very abundant $\left(0.5-1.5 \times 10^{6}\right.$ ind. $\left.\mathrm{m}^{-2}\right)$ as are a great variety of mesoplankton species.

Although there is a slow increase in mesozooplankton biomass during the summer, it is not until the latter part of September that the abundance reaches high values (Fig. 6). This coincides with the decrease in abundance of Aurelia aurita starting in September.

In the period October/December, with maximum biomass values, the planktonic fauna is mainly composed of copepods. Calanus finmarchicus, Pseudocalanus elongatus and Microcalanus pusillus dominate the deeper layers, while Acartia longiremis, A. clausi and Temora longicornis are most frequent in the water body above sill depth. The cyclopoid Oithona similis is common throughout the water column.

\section{DISCUSSION}

During spring 1980 the benthic fauna in the deep basin of the fjord had completely disappeared due to oxygen deficiency (Josefson, 1981). This has never been reported before; whether it was a unique event or not, something essential must have happened to this 'clean and not eutrofied' fjord. The oxygen deficiency probably resulted from a combination of poor exchange of deep water and a heavy bloom of sedimenting phytoplankton, increasing both the amount of organic matter and the oxygen demand in the deep water.

An oxygen deficiency which caused a complete wipe-out of the benthic fauna and disappearance of fish in the Bay of Laholm on the southwest coast of Sweden (Fig. 1) caused newspaper headlines in autumn 1980. Marine biologists discovered an extremely high abundance of dinoflagellates (Ceratium spp.) in the Bay, and it was the decomposition of masses of these algae - together with badly ventilated deep water in the Bay - that caused the anoxic conditions (Edler, in press). The Bay of Laholm is situated $300 \mathrm{~km}$ south of the Gullmar Fjord on the west coast in an agricultural area and it was at first thought that excessive nutrients from farming caused the heavy bloom.

Were oxygen deficiencies in the Bay of Laholm and the Gullmar Fjord related events? When enquiries were made and the literature examined, it was appa- rent that we were dealing with a widespread phenomenon.

Comparisons of the sparse material from earlier investigations from the west coast of Sweden - Göteborgs Vatten- och Avloppsverk (1972), Óström (1974) and Söderström et al. (1976) - suggest that the primary production has increased a little, but more significantly the chlorophyll $a$ and cell numbers. Unfortunately, primary production results of these investigations were reported in a form which renders comparisons very difficult. The apparent increase in productivity during the 1970's may be a result of technical advances in the analytical technique and/or in a higher sampling frequency. However, primary production values obtained in the Gullmar Fjord are in good accordance with recent results found at Tjärnö Marine Biological Station (Fig. 1) situated $100 \mathrm{~km}$ further north (Lännergren, pers. comm.).

Peak values of chlorophyll $a_{r}$ cell numbers and biomass measured in this study are far above those found earlier in the area; they are much higher than in the Sound (Edler, 1977) and similar to those in the Oslo Fjord (Braarud, 1969) - both known to be eutrophied and polluted areas. Algal blooms have previously been reported from the west coasts of Norway and Denmark (Tangen, 1977), but blooms - and particularly mass occurrences of Ceratium spp. and G. aureolum - are new phenomena in the area.

In our investigation, the 'spring bloom' starts earlier than what is generally considered 'spring'. February and March show the highest chlorophyll a values (Fig. 5) even under an ice-cover of $30 \mathrm{~cm}$. Interpreted as an increase in 'season length', this would be in accordance with situations described for the North Sea by Reid (1978) and Colebrook and Coombs (1978). As mentioned above, at this time of the year the euphotic zone is practically uninhabited by zooplankton (except for barnacle nauplii). An increased period of phytoplankton production is, therefore, liable to cause increased sedimentation of organic matter.

During early summer, a conspicuous increase in zooplankton diversity takes place, mainly among the copepods. However, contrary to what Hernroth and Ackefors (1979) have found in the Baltic Sea, this build-up does not reach a high biomass. The reason for this limitation of zooplankton is probably the invasion of Aurelia aurita which seems to regulate the whole pelagic system during the summer. Moller (1977) showed that mass occurrence of $A$. aurita in Kiel Bight was responsible for a decrease in copepod stocks and documented statistically heavy predation of adult $A$. aurita on fish larvae. Kerstan (1977) states that ephyra larvae consume a variety of diatoms, and larger medusae predate on chain-forming diatoms, flagellates, cladocerans, copepods and bivalve larvae - in 
short, everything from detritus to fish $22 \mathrm{~mm}$ long can be found in their gut contents.

Thus, it seems likely that the energy of local primary production and the rich variety of zooplankton organisms is channelled towards 'a dead end in the energy transfer' (Kerstan, 1977). This means that little or no energy is transferred to higher thophic levels. The biomass stored in scyphomedusae (Cyanea is also abundant) must be high; with no predators present, the contribution of dying scyphomedusae to deep-water oxygen decrease could be considerable.

Indicative of a regulating effect due to Aurelia aurita is the rapid rise in mesoplankton biomass when the medusae decline in abundance in September/October. This mesozooplankton biomass (mainly herbivorous and omnivorous copepods) remains fairly high throughout autumn (Fig. 6). The availability of algal food seems, according to chlorophyll-values (Fig. 5), to be more than sufficient. However, the peaks in October of 1978 and 1979 with chlorophyll maxima of $25 \mathrm{mg}$ $\mathrm{m}^{-3}$ and primary production values of 1,000 to 1,400 $\mathrm{mg} \mathrm{C} \mathrm{m} \mathrm{m}^{-2} \mathrm{~d}^{-1}$ are almost entirely the result of the very high abundance of Ceratium spp. According to literature, it is not clearly established whether Ceratium can be consumed by copepods. While Elbrächter (1973) found thecae of Ceratium in fecal pellets of copepods (thought to suck out the plasma of these algae) he recorded no grazing in isolated copepods presented Ceratium as only food source. Performing feeding experiments with natural phytoplankton populations (same species of copepods as in Gullmar Fjord) Hargrave and Geen (1970) found that Ceratium and Chaetoceros were not ingested. On the other hand, Schnack (1976) reports that Temora longicornis is generally able to feed on Ceratium and assumes that the algae had been sucked out. She points out, however, that $T$. longicornis feeds on a rather large size spectrum compared to many other copepods.

Why did the relatively small Gyrodinium aureolum increase to such an enormous abundance in autumn 1981? According to Tangen (1977) G. aureolum can be poisonous to certain fish and invertebrates; it is uncertain, however, whether this applies also to the planktonic fauna. However, Artemia nauplii can be affected by $G$. aureolum (Helm et al., 1974). It seems possible that the grazing pressure was reduced not only by the scyphomedusae but also by the toxicity of this particular algae. Should this new immigrant become established, it would be necessary to investigate the relationship between the regularly appearing zooplankton and $G$. aureolum.

Our data suggest that the tremendous bloom of dinoflagellates that has occurred in recent years (peaks of

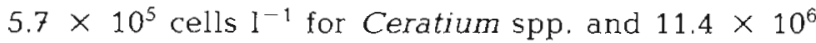
cells $1^{-1}$ for Gyrodinium aureolum) is not fully utilized in the pelagic zone. While there is, of course, decomposition and recycling in the upper water layers, we suspect that much of the algal biomass is transported into the deeper layers. It would thus be understandable why areas with poor water exchange are more frequently depleted of oxygen. Fig. 3 witnesses a pronounced decrease in oxygen each autumn; the figures at maximum depth $(120 \mathrm{~m})$ are even lower. Poor water exchange, as in 1979, would result in a disruption of the benthic community.

We also have indications of a decrease of total mesozooplankton biomass from 1978 to 1981. In fact, the proportion algae/zooplankton in our regular netzooplankton samples is so large, that a displacement method for zooplankton biomass estimation is difficult to perform. Earlier, the algae used to 'contaminate' the samples only during shorter periods in spring and autumn, but today the relationship phyto-/zooplankton is high almost throughout the year. Even hauls from $120 \mathrm{~m}$ depth with a $200 \mu \mathrm{m}$ net very often yield too little zooplankton in relation to phytoplankton for using a displacement method.

What are the reasons for the 'abnormalities' observed? Since so many of our observations are in agreement with situations prevailing not only along the Swedish west coast, but also throughout the southern Baltic Sea, the Kattegatt, the North Sea and other areas, we believe that this is a large-geographicalscale phenomenon, such as suggested by Colebrook (1978), Colebrook and Coombs (1978), Reid (1978) and Gillbricht (pers. comm.). Furthermore, there are several reports (e.g. Dickson et al., 1975) on hydrometeorological changes in the North Atlantic Region that have taken place in the last 20 to $30 \mathrm{yr}$.

In our opinion it may very well be that climatic alterations initiated the changes observed in the pelagic ecosystem. If impact due to man's activities has, at the same time, altered the food webs of the pelagic zone by intense over-fishing of pelagic species as suggested by Sherman (1978), this may have augmented the natural changes.

In the Sound (Fig. 1), phosphate concentrations of surface waters have increased 9-fold since 1940 (Edler, 1977). At Fladen, Kattegatt, a smaller but statistically significant increase in total phosphorus concentrations over the past $15 \mathrm{yr}$ has been observed (A. Svansson, pers. comm.). However, our own data together with Anonymous $(1975,1976,1977,1978,1979,1980)$ show no increase in phosphate values during the last $15 \mathrm{yr}$ in the Gullmar Fjord.

According to Granéli (1981), nitrogen is the limiting nutrient for primary production in the Sound. It is thus reasonable to assume that this also is true in the Gullmar Fjord. Unfortunately, there are too few measurements on nitrogen along the coast to establish any 
definite trend. Increased use of fertilizers during recent years, together with lack of nitrogen reduction in sewage plants, suggests that the total amounts of nitrogen compounds released have increased.

On the other hand, a limited increase in primary production has possibly taken place, and dramatic increases in chlorophyll and cell numbers have been found. This supports our assumption that a reduction in grazing pressure may be a more likely explanation while we do not deny a possible role of eutrophication. According to Hay and Hislop (1980), Aurelia aurita was very abundant west of Denmark in 1978 and 1979. In 1980 , according to the same authors (1981), it was somewhat less abundant than in the 2 previous years. This agrees with our observations on the Swedish west coast where mass invasions occurred in 1978, 1979 and 1981. The concomitant occurrence of algal blooms $(1978,1979,1981)$ and invasions of $A$. aurita suggest a causative correlation. In this connection, the very low biomass of mesozooplankton is conspicuous. The biomass remains low throughout the summer until the decrease in scyphomedusae in September/October. A. aurita significantly reduced the grazing pressure and thus allowed the algal population to grow. If, in addition, the algae constituting the blooms are either difficult to graze on or poisonous, the effects should be even more pronounced.

Acknowledgements. This project was financed by grants from the Swedish Environmental Protection Agency and the Swedish Natural Science Research Council. Our gratitude is also extended to Professor W C. Summers, Western Washington University, who made valuable comments on our manuscript as well as linguistic corrections.

\section{LITERATURE CITED}

Anonymous (1975-1980). Hydrographical data Nos. 1, 2, 3, 4 $5,6,7,10,12,14,15,16,17$ and 20. Fish. Bd Sweden, Inst. of Hydrographic Res.

Baltic Marine Biologists (1976). Recommendations on methods for marine biological studies in the Baltic Sea. BMB Publ. No. 1: 1-98 (Copies available from Askö Laboratory Library, Dept. of Zool., Univ. of Stockholm, Box 6801, S-113 86 Stockholm, Sweden)

Baltic Marine Biologists (1979). Recommendations on methods for marine biological studies in the Baltic Sea. Phytoplankton and chlorophyll. BMB Publ. No. 5: 1-38 (Copies available from Dept, of Marine Botany, Univ, of Lund, Box 740, S-220 07 Lund, Sweden)

Braarud, T. (1969). Pollution effect upon the phytoplankton of the Oslofjord. ICES CM 1969/L: 15 (mimeo)

Carrit, D. E., Carpenter, J. H. (1966). Comparison and evaluation of currently employed modifications of the Winkler method for determining dissolved oxygen in sea water; $A$ NASCO report. J. mar. Res. 24 (3): 286-318

Colebrook, J, M. (1978). Changes in the zooplankton of the North Sea 1948-1973. Rapp. P.-v. Réun. int. Explor, Mer 172: $390-396$
Colebrook, P. C., Coombs, S. H. (1978). Continuous plankton records: a change in the plankton of the southern North Sea between 1970 and 1972. Mar. Biol. 45: 209-213

Dickson, R. R., Lamb, H. H., Malmberg, S. A., Colebrook, J. M. (1975). A climate reversal in the North Atlantic. Nature, Lond. 256: 479-481

Edler, L. (1977). Phytoplankton and primary production in the Sound, Ph. D thesis, Dept. of Mar. Bot., Univ, of Gothenburg, Gothenburg, Sweden

Edler, L. (in press). A mass development of Ceratium species on the Swedish West Coast. Limnologica 15 (2)

Elbrächter, M. (1973). Population dynamics of Ceratium in coastal waters of the Kiel Bay. Oikos 15 (Suppl.): 43-48

Granéli, E. (1981). Experimental investigations of limiting nutrients for phytoplankton production in the brackish water Oresund, S. W. Sweden. Ph. D. thesis, Dept. of Mar. Bot., Univ. of Lund, Lund, Sweden

Göteborgs Vatten- och Avloppsverk (1972). Göteborgs Vattenvårdsanläggningar - Recipientundersökningar år 1970-1971, Göteborgs V.A.verk 12. 5. 1972, (mimeogr. report)

Hargrave, B. T., Geen, G. H. (1970). Effects of copepods grazing on two natural phytoplankton populations. J. Fish. Res. Bd Can. 27: 1395-1403

Hay, S. J., Hislop, J. R. G. (1980). The distribution and abundance of Scyphomedusae in the North Sea during the summer 1979. ICES CM 1980/L: 25 (mimeo)

Hay, S. J., Hislop, J. R. G. (1981). The distribution and abundance of Scyphomedusae in the North Sea during the summer of 1980. ICES CM 1981/L: 22 (mimeo)

Helm, M. M., Happer, T B., Spencer, B. E., Walne, P. R. (1974). Lugworm mortalities and a bloom of Gyrodinium aureolum Hulbert in the eastern Irish Sea, Autumn 1971. J. mar. biol. Ass. U. K. 54: 857-869

Hernroth, L., Ackefors, H. (1979). The zooplankton of the Baltic Proper - a long-term investigation of the fauna, its biology and ecology. Report, Fish. Bd Sweden, Inst. Mar Res. No. 2: $60 \mathrm{pp}$

I.C.E.S. (1976). Report on the working group on red tides and eutrophication. ICES CM 1976/L: 39 (mimeo)

Josefson, A. B. (1981). Effekter av syrebrist och långsiktiga förändringar av bottensediment på den makrobentiska infaunan i Gullmarsfjordens djupbassäng. (mimeogr. report, KMBS, S-450 34 Fiskebäckskil, Sweden)

Kerstan, M. (1977). Untersuchungen zur Nahrungsökologie von Aurelia aurita Lam. Diplomarbeit math.-nat. Fak. Univ. Kiel, F. R. Germany

Lindley, J. A. (1979). Continuous plankton records: an increase in the abundance of euphausids in the eastern central Noith Sea. ICES CM 1979/L: 25 (mimeo)

Möller, H. (1977). Significance of coelenterates in relation to other organisms. ICES CM 1977/L: 3 (mimeo)

Óström, B. (1974). Physical-chemical conditions, nutritional ability and related ecological aspects of Brofjorden. Fish. Bd Sweden, Inst. of Hydrographic Res., Medd. No. 176 (mimeo)

Reid, P. C. (1978). Continuous plankton records: large-scale changes in the abundance of phytoplankton in the North Sea from 1958-1973. Rapp. P.-v. Réun. Cons. int. Explor. Mer 172: 384-389

Rydberg، L. (1977). Circulation in the Gullmaren - a sill fjord with extemally maintained stratification. Inst. of Oceanography, Univ. of Gothenburg, Report No. 23 (mimeo.

Schnack, S. (1976). Preliminary studies on the importance of Ceratium as food tor copepods. ICES CM 1976/L: 30 (mimeo) 
Sherman, K. (1978). Ecological implications of biomass changes in the Northwest Atlantic. ICES CM 1978/L: 24 (mimeo)

Strickland, J. D. H, Parsons, T. R. (1960). A manual of seawater analysis. Determination of phytoplankton pigments. Bull. Fish. Res. Bd Can. 125

Strickland, J. D. H., Parsons, T. R. (1968). A practical handbook of sea water analysis. Bull. Fish. Res. Bd Can. 167

Söderström, J., Rex, B., Rex, M., Hildenwall, E. (1976). The
By Fjord - Marine Botanical Investigations. Swedish Environmental Protection Agency, SNV PM 684, Dept. of Marine Botany, Univ. of Gothenburg

Tangen, K. (1977). Blooms of Gyrodinium aureolum (Dinophyceae) in north European waters, accompanied by mortality in marine organisms. Sarsia 63 (2): 123-133

Utermöhl, $H$. (1958). Zur Vervollkommnung der quantitativen Phytoplankton-Methodik. Mitt. int. Verein. Limnol. 9: 1-38

This paper was presented by Dr. J. J. Zijlstra; it was accepted for printing on August 3, 1982 